International Journal of Small Business and Entrepreneurship Research

Vol.8, No.3, pp.31-42, June 2020

Published by ECRTD-UK

Print ISSN: 2053-5821(Print), Online ISSN: 2053-583X (Online)

\title{
FACTORS AFFECTING THE CAPITAL STRUCTURE: A CASE STUDY OF REAL ESTATE COMPANIES LISTED ON STOCK MARKET IN VIETNAM
}

\author{
Tran Thi Mong Tuyet, \\ University of Economics Ho Chi Minh City (UEH) \\ Mai Thanh Loan, \\ Van Lang University (VLU)
}

\begin{abstract}
The real estate market plays a significant role in the development of the economy. It is a factor contributing to promote investment capital mobilization, to improve production and development. This market is increasing state budget revenues, expanding markets, and contributing to socio-economic stability. Therefore, this study conducted to find the relationship of factors with the capital structure for real estate companies, in particular, real estate companies listed on Vietnam's stock market. The researchers used multiple regression analysis, the capital structure status of real estate companies surveyed from 2017 to 2019. The sample included 94 real estate companies listed on the stock market in Vietnam. The research results found out the factors that affect the capital structure. These results had a scientific basis to help real estate companies refer to adjusting their capital structure, contributing to improving their competitive ability and development of the real estate.
\end{abstract}

Keywords: Capital, structure, stock, market, and real estate.

\section{INTRODUCTION}

In 2018, It considered being a relatively successful year of the real estate market in Vietnam when the market develops steadily. Market segments and products have changed in more cognitive restructuring. The supply and volume of successful transactions in the real estate market have grown well, contributing to the overall growth of Vietnam's economy. According to experts' forecast, the real estate market in 2019 continued to face many challenges when the credit flow tightened, the macroeconomic policies, and the US-China trade war, have created specific effects. The survey shows that, in the first five months of 2019, the real estate market has witnessed sharp fluctuations in price, supply, and volume of successful transactions under different scenarios across market segments, namely:

Housing real estate market: in two big cities, Hanoi and Ho Chi Minh City (HCMC). HCMC moved in opposite directions in the number of offers and prices. In Hanoi, in the first quarter of 2019, the condominium market had the highest number of launches compared to the previous quarters, with a total of 11,822 units launched and 9,390 units sold successfully. In HCMC, there were 4,423 apartments offered for sale with a decrease of $46 \%$ compared to the fourth quarter of 2018, while the supply decreased, but the number of successful transactions reached 5,924 apartments (ie, the market has released about 1,500 apartments inventory). 
International Journal of Small Business and Entrepreneurship Research

Vol.8, No.3, pp.31-42, June 2020

Published by ECRTD-UK

Print ISSN: 2053-5821(Print), Online ISSN: 2053-583X (Online)

In terms, selling prices of the first quarter of 2019, the average selling price on the primary market in both Hanoi and HCMC. HCMC increased slightly, ranging from $1 \%-3 \%$ compared to the previous quarter. The mid-end segment still holds the most significant proportion of total transaction volume. Social housing only meets $30 \%$ of the demand. In the coming time, social housing and affordable housing are forecast to be the segment with strong demandthe real estate market in Hanoi and HCMC. HCMC still tends to move to the suburbs, away from the central areas. With the current economic context, the difficulties of the real estate business have not stopped. Although interest rates have now dropped significantly and interest rates lowered soon, there will certainly not be much more. Besides, the weakening of the economy and tightening credit policy for the real estate industry will make it difficult for this industry to recover quickly. Therefore, the author chose the topic "Factors affecting the capital structure: a case study of real estate companies listed on the stock market in Vietnam" to help real estate companies determine an appropriate capital structure to maintain, overcome difficulties and develop sustainably in the future.

\section{LITERATURE REVIEW}

Fixed assets (FA) and financial leverage (LEV: Debt/Total assets; STD: short-term debt/Total assets; LTD: Long-term debt /total assets)

Tangible fixed assets are as a guarantee for corporate loans, which will impact on different levels of debt (Bauer, P, 2014). Moreover, tangible fixed assets can influence a firm's debt decision because they are less likely to have asymmetric information and are more valuable than intangible fixed assets in the event of bankruptcy. The higher the percentage of tangible fixed assets on the balance sheet (Tangible fixed assets on total assets), the lenders will be willing to provide loans, and the financial leverage will be higher (Bhaduri, Saumitra N, 2015). Firms with a high proportion of tangible fixed assets usually belong to less risky industries, when they can create higher financial leverage and a higher percentage of tangible fixed assets.

Hypothesis H1: Fixed assets have a positive impact on the financial leverage of real estate companies listed on the Vietnam stock market.

Growth (GRO) and financial leverage (LEV: Debt/Total assets; STD: short-term debt/Total assets; LTD: Long-term debt /total assets)

According to the trade-off theory, companies with more growth opportunities in the future tend to have less debt because growth opportunities did not use as collateral for loans (Chen, J. J, 2017). Firms with higher growth opportunities are more likely to invest in lucrative investments or accept high-risk projects to leverage assets from creditors. However, this will increase borrowing, so developers are more likely to use resources within the company than to borrow (Gulnur Muradoglu, 2018). Therefore, growth opportunities are negatively related to financial leverage.

Hypothesis H2: Growth affecting a negative on the financial leverage of real estate companies listed on the Vietnam stock market. 
International Journal of Small Business and Entrepreneurship Research

Vol.8, No.3, pp.31-42, June 2020

Published by ECRTD-UK

Print ISSN: 2053-5821(Print), Online ISSN: 2053-583X (Online)

Liquidity (LIQ) and financial leverage (LEV: Debt/Total assets; STD: short-term debt/Total assets; LTD: Long-term debt/total assets)

Liquidity considered to be inverse to debt, so it reduces the demand for debt (I. M. Pandey, 2016); this reversal stems from potential conflicts between shareholders and bondholders. The reason is that the higher the liquidity, the more shareholders can easily take advantage of the company's liquid assets, which is not suitable for bondholders. Sharing the view with (Joy Pathak, 2014), we agree that solvency in which cash accumulates and other current assets will serve as an internal fund and will be used first instead of debt.

Hypothesis H3: Liquidity affecting a negative on the financial leverage of real estate companies listed on the Vietnam stock market.

Return on assets (ROA) and financial leverage (LEV: Debt/Total assets; STD: short-term debt/Total assets; LTD: Long-term debt /total assets)

According to the trade-off theory, profitable firms will borrow heavily loan because they take advantage of tax shields and low risk of bankruptcy. On the other hand, according to the classification order theory, (Lee, C. F, 2018) argued that performance and debt are inversely related because successful businesses will not need to rely heavily on the source. External capital can finance their operations from the profits gained in the past (Mackies-Mason J, 2015).

Hypothesis H4: Return on assets affecting a negative on the financial leverage of real estate companies listed on the stock market in Vietnam.

Firm size (SIZE) and financial leverage (LEV: Debt/Total assets; STD: short-term debt/Total assets; LTD: Long-term debt /total assets)

Most empirical studies have shown a positive relationship between firm size and financial leverage. (Myers J. K, 2017) shows that The firm size factor is positively correlated and with financial leverage and is statistically significant in companies of 21 countries out of 42 countries surveyed. Company size measured by the logarithm of total revenue or the logarithm of total assets. (Ozkan, A, 2016) argue that the logarithm transformation of revenue reflects the impact of firm size, and therefore we take the logarithm of total revenue for our calculation.

Hypothesis H5: Firm size affecting a positive on the financial leverage of real estate companies listed on the Vietnam stock market in Vietnam.

Ratio of state ownership (STATE) and financial leverage (LEV: Debt/Total assets; STD: short-term debt/Total assets; LTD: Long-term debt /total assets)

According to the author, the ratio of state capital in an enterprise is positively (+) related to financial leverage for the following reasons:. First, due to the relationship before the enterprise equitized, creditors are often ready to lend to state-owned enterprises (Paudyal, K, 2017).

Second, the management of high-state-owned enterprises is more likely to make decisions that deviate from maximizing corporate value, such as using the resources of profitable businesses. 
International Journal of Small Business and Entrepreneurship Research

Vol.8, No.3, pp.31-42, June 2020

Published by ECRTD-UK

Print ISSN: 2053-5821(Print), Online ISSN: 2053-583X (Online)

For them (Lee, C. F, 2018). Therefore, the debt ratio is high as a tool to monitor the management of the company.

Hypothesis H6: Ratio of state ownership affecting a positive on the financial leverage of real estate companies listed on the Vietnam stock market.

Tangibility (TANG) and financial leverage (LEV: Debt/Total assets; STD: short-term debt/Total assets; LTD: Long-term debt /total assets)

Tangible assets are characteristics that an asset can be used as collateral to secure debt. (Mackies-Mason J, 2015) argue that firms with larger collateral values tend to use debt more because the cost of debt representation is lower than that of firms with small collateral values. Higher tangible assets represent a lower lender's risk as well as lower bankruptcy costs. Among the various factors that determine the company's capital structure selection, it is essential to mention the high bankruptcy costs (Vidhan K. Goyal, 2016).

Hypothesis H7: Tangibility has a positive impact on the financial leverage of real estate companies listed on the Vietnam stock market.

\section{Corporate income tax (TAX) and financial leverage (LEV: Debt/Total assets; STD: short- term debt/Total assets; LTD: Long-term debt/total assets)}

provided the reason why studies fail to find significant tax effects on financial behavior, which mentioned in Mackie-Mason's theory because The debt-to-equity ratio is a year-over-year accumulation of different decisions and most tax shields have little impact on the tax rates of most businesses (Raviv, A, 2017). Mackie-Mason studies quantitative financial decisions with separate analyzes (Zou, H, 2017).

Hypothesis H8: Corporate income tax has a positive impact on the financial leverage of real estate companies listed on the Vietnam stock market.

Uniqueness (UNI) and financial leverage (LEV: Debt/Total assets; STD: short-term debt/Total assets; LTD: Long-term debt /total assets)

Product specificity measured by the ratio of goods sold total net sales. Businesses with unique products often have low financial leverage because it goes bankrupt (Wiwattanakantang Y, 2017). The competitive secondary market for inventories and production equipment of the business may not be available, leading to low recovery values (Wessels, R, 2017). Because of the real estate industry that focused on technology, inventory is mainly real estate goods and unfinished construction real estate, so the uniqueness of the product is low (Yermack, D. L, 2016).

Hypothesis H9: Uniqueness affecting a negative on the financial leverage of real estate companies listed on the Vietnam stock market. 
International Journal of Small Business and Entrepreneurship Research

Vol.8, No.3, pp.31-42, June 2020

Published by ECRTD-UK

Print ISSN: 2053-5821(Print), Online ISSN: 2053-583X (Online)

Table 1: The hypothesis for factors affecting the financial leverage of real estate companies listed on the Vietnam stock market

\begin{tabular}{|c|c|c|}
\hline Hypothesis & Code & $\begin{array}{c}\text { Impact on the } \\
\text { financial leverage }\end{array}$ \\
\hline H1 & FA & + \\
\hline H2 & GRO & - \\
\hline H3 & LIQ & - \\
\hline H4 & ROA & - \\
\hline H5 & SIZE & + \\
\hline H6 & STATE & + \\
\hline H7 & TANG & + \\
\hline H8 & TAX & + \\
\hline H9 & UNI & - \\
\hline
\end{tabular}

Table 1 showed that hypothesis following:

(Source: The researchers' collecting)

Hypothesis H1: Fixed assets have a positive impact on financial leverage;

Hypothesis H2: Growth affecting a negative on financial leverage;

Hypothesis H3: Liquidity affecting a negative on financial leverage;

Hypothesis H4: Return on assets affecting a negative on financial leverage;

Hypothesis H5: Firm size affecting a positive on financial leverage;

Hypothesis H6: Ratio of state ownership has a positive impact on financial leverage;

Hypothesis H7: Tangibility affecting a positive on financial leverage;

Hypothesis H8: Corporate income tax has a positive impact on financial leverage;

Hypothesis H9: Uniqueness affecting a negative on financial leverage.

The authors proposed the research model for factors affecting the financial leverage of real estate companies listed on the Vietnam stock market in Vietnam.

Model 1: $\mathrm{LEV}=\beta_{0}+\beta_{1} \mathrm{FA}+\beta_{2} \mathrm{GRO}+\beta_{3} \mathrm{LIQ}+\beta_{4} \mathrm{ROA}+\beta_{5} \mathrm{SIZE}+\beta_{6} \mathrm{STATE}+$ $\beta 7 \mathrm{TANG}+\beta 8 \mathrm{TAX}+\beta 9 \mathrm{UNI}+\varepsilon_{\mathbf{i}}$

Model 2: $\mathrm{STD}=\beta_{0}+\beta_{1} \mathrm{FA}+\beta_{2} \mathrm{GRO}+\beta_{3} \mathrm{LIQ}+\beta_{4} \mathrm{ROA}+\beta_{5} \mathrm{SIZE}+\beta_{6} \mathrm{STATE}+$ $\beta 7$ TANG $+\beta 8$ TAX $+\beta 9$ UNI $+\varepsilon \mathrm{i}$ 
International Journal of Small Business and Entrepreneurship Research

Vol.8, No.3, pp.31-42, June 2020

Published by ECRTD-UK

Print ISSN: 2053-5821(Print), Online ISSN: 2053-583X (Online)

\begin{abstract}
Model 3: $\mathrm{LTD}=\beta_{0}+\beta_{1} \mathrm{FA}+\beta_{2} \mathrm{GRO}+\beta_{3} \mathrm{LIQ}+\beta_{4} \mathrm{ROA}+\beta_{5} \mathrm{SIZE}+\beta_{6} \mathrm{STATE}+$ $\beta 7 \mathrm{TANG}+\beta 8 \mathrm{TAX}+\beta 9 \mathrm{UNI}+\varepsilon_{\mathrm{i}}$

Note: LEV (leverage); STD (short-term debt) and LTD (long-term debt)

\section{METHODS OF RESEARCH}

To implement the topic, the author qualitatively studied the technical documents, previous studies to format the research model. Since then, apply quantitative research on econometric models. The research process for factors affecting the financial leverage of real estate companies listed on the stock market in Vietnam having three phases following.

Phase 1: Researchers applied the expert methodology and based on ten experts' consultation about the financial model to improve the questionnaire. The authors surveyed ten experts who agreed that all of the factors affecting the financial leverage of real estate companies listed on the stock market in Vietnam. Researchers created a list of possible factors gathered from the literature reviews, as mentioned in the above studies (Hair, B. B., \& Anderson, 2010).

Phase 2: Researchers tested the factors affecting the financial leverage of real estate companies listed on the stock market in Vietnam based on 30 samples are from real estate companies listed on the stock market in Vietnam. The data got from 2017 to 2019 in companies listed on the stock market in Vietnam. Simple random sampling technique. The data applied multiple regression analysis.

Phase 3: Researchers applied the least-squares method and multiple linear regression used (Hair, Anderson, Tatham, \& Black, 1998). A least-squares method is a form of mathematical regression analysis that finds the line of best-fit data, providing a visual demonstration of the relationship between the data points. Each data represented the relationship between independent variables and a dependent variable (Hair, B. B., \& Anderson, 2010). The researchers collected 94 real estate companies listed on the stock market in Vietnam. The data got from 2017 to 2019 in companies listed on the stock market in Vietnam. Simple random sampling technique. The data applied multiple regression analysis - data processed by SPSS 20.0 and testing hypotheses.

The researchers had the conclusions and recommendations. 
International Journal of Small Business and Entrepreneurship Research

Vol.8, No.3, pp.31-42, June 2020 Published by ECRTD-UK

Print ISSN: 2053-5821(Print), Online ISSN: 2053-583X (Online)

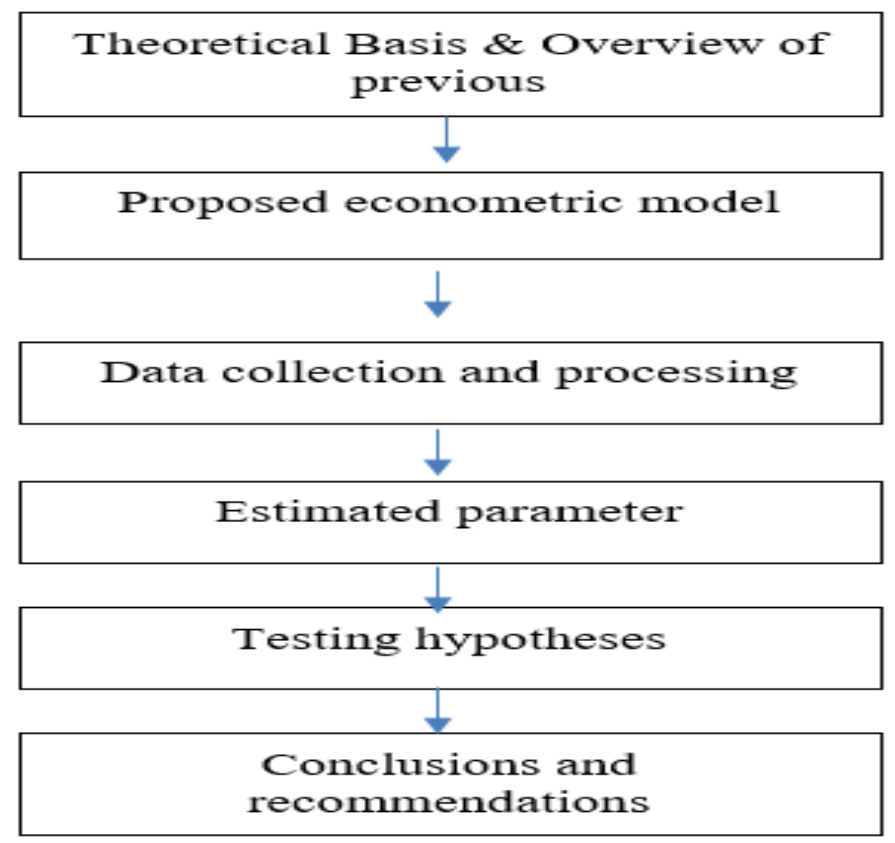

Source: The researchers' collecting

Figure 1: The research process for factors affecting the financial leverage of real estate companies listed on the stock market in Vietnam

\section{RESEARCH RESULTS}

Testing for factors affecting the financial leverage of real estate companies listed on the stock market in Vietnam

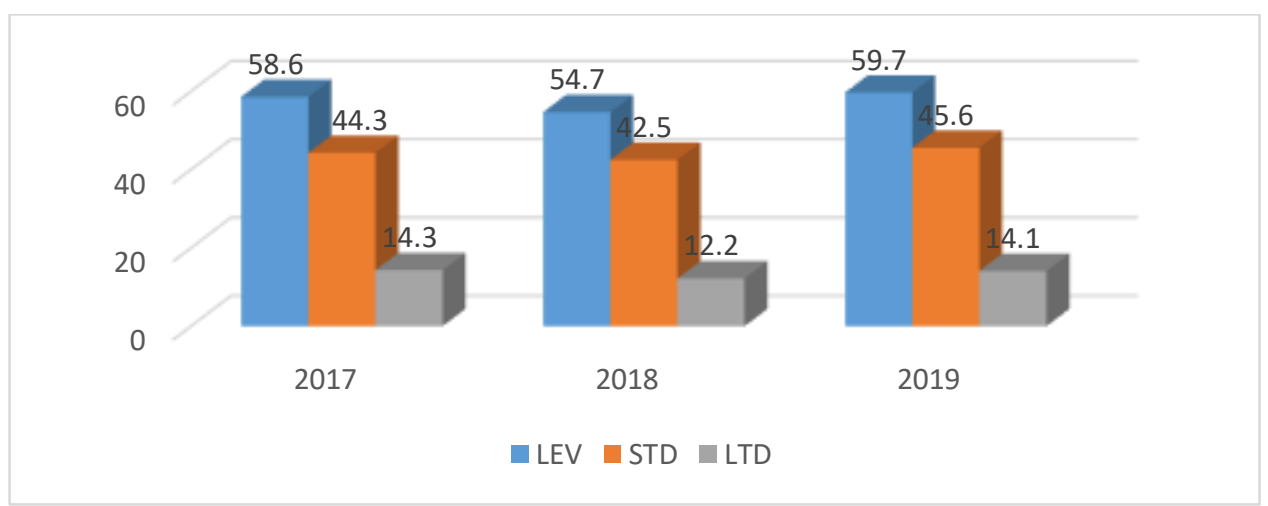

(Source: The researchers' collecting data and SPSS 20.0)

Figure 2: The capital structure of real estate companies listed on the stock market in Vietnam 
International Journal of Small Business and Entrepreneurship Research

Vol.8, No.3, pp.31-42, June 2020

Published by ECRTD-UK

Print ISSN: 2053-5821(Print), Online ISSN: 2053-583X (Online)

Figure 2 showed the capital structure of real estate companies listed on the Vietnam stock market year by year.

Table 1: Tested results of model 1 for factors affecting the financial leverage of real estate companies listed on the stock market in Vietnam

\begin{tabular}{|c|c|c|c|c|c|c|c|}
\hline \multirow{2}{*}{ Model } & \multicolumn{2}{|c|}{$\begin{array}{c}\text { Unstandardized } \\
\text { Coefficients }\end{array}$} & \multirow{2}{*}{$\begin{array}{c}\text { Standardized } \\
\text { Coefficients }\end{array}$} & \multirow{2}{*}{$\mathrm{t}$} & \multirow{2}{*}{ Sig. } & \multicolumn{2}{|c|}{$\begin{array}{l}\text { Collinearity } \\
\text { Statistics }\end{array}$} \\
\hline & B & Std. Error & & & & Tolerance & VIF \\
\hline (Constant) & 0.57 & 0.225 & & 2.534 & 0.013 & & \\
\hline FA & 0.106 & 0.033 & 0.118 & 3.213 & 0.005 & 0.797 & 1.254 \\
\hline GRO & -0.185 & 0.056 & -0.295 & -3.332 & 0.001 & 0.900 & 1.111 \\
\hline LIQ & -0.061 & 0.013 & -0.459 & -4.813 & 0.000 & 0.774 & 1.292 \\
\hline ROA & -1.161 & 0.390 & -0.276 & -2.976 & 0.004 & 0.818 & 1.222 \\
\hline 1 SIZE & 0.115 & 0.032 & 0.041 & 3.593 & 0.002 & 0.930 & 1.075 \\
\hline STATE & 0.022 & 0.041 & 0.048 & 0.539 & 0.591 & 0.898 & 1.114 \\
\hline TANG & 0.297 & 0.077 & 0.349 & 3.874 & 0.000 & 0.867 & 1.154 \\
\hline TAX & 0.009 & 0.027 & 0.030 & 0.34 & 0.735 & 0.935 & 1.069 \\
\hline UNI & -0.116 & 0.055 & -0.136 & -2.109 & 0.030 & 0.819 & 1.221 \\
\hline a. Dependen & e: LEV & & & & & & \\
\hline
\end{tabular}

(Source: The researchers' collecting data and SPSS 20.0)

Table 1 showed that all nine variables surveyed that is very reliable. Such observations make it eligible for the survey variables after the testing. This factor showed that data was suitable and safe for researching. The ratio of total debt to assets (LEV) eliminated: the state ownership ratio (STATE), the marginal tax rate (TAX) are not significant at 5 percent.

From the model, we can conclude:

The ratio of total debt to total assets influenced by the following factors: FA, GRO, LIQ, ROA, SIZE, TANG, and UNI with significance at 5 percent.

Table 1 showed that real estate investment requires a large amount of investment capital and long-term investment period, individuals or project owners often do not have enough capital to fund projects or the need to own real estate. Therefore, they usually have to look to banks as a place that can provide abundant capital in the long term. Meanwhile, the high-profit margin of the real estate market has attracted more and more banks to engage in credit financing for real estate investment projects as well as funding for real estate. The loan needs to buy houses and land. 
International Journal of Small Business and Entrepreneurship Research

Vol.8, No.3, pp.31-42, June 2020

Published by ECRTD-UK

Print ISSN: 2053-5821(Print), Online ISSN: 2053-583X (Online)

Table 2: Tested results of model 2 for factors affecting the financial leverage of real estate companies listed on the stock market in Vietnam

\begin{tabular}{|c|c|c|c|c|c|c|c|}
\hline \multirow{2}{*}{ Model } & \multicolumn{2}{|c|}{$\begin{array}{c}\text { Unstandardized } \\
\text { Coefficients }\end{array}$} & \multirow{2}{*}{$\begin{array}{c}\text { Standardized } \\
\text { Coefficients }\end{array}$} & \multirow{2}{*}{$\mathrm{t}$} & \multirow{2}{*}{ Sig. } & \multicolumn{2}{|c|}{$\begin{array}{l}\text { Collinearity } \\
\text { Statistics }\end{array}$} \\
\hline & B & Std. Error & & & & Tolerance & VIF \\
\hline (Constant) & 0.725 & 0.209 & & 3.463 & 0.001 & & \\
\hline FA & -0.514 & 0.087 & -0.47 & -5.941 & 0.000 & 0.797 & 1.254 \\
\hline GRO & 0.145 & 0.052 & 0.209 & 2.812 & 0.006 & 0.900 & 1.111 \\
\hline LIQ & -0.097 & 0.012 & -0.661 & -8.242 & 0.000 & 0.774 & 1.292 \\
\hline ROA & -0.107 & 0.033 & -0.023 & -3.242 & 0.002 & 0.818 & 1.222 \\
\hline $2 \mathrm{SIZE}$ & -0.03 & 0.03 & -0.072 & -0.983 & 0.328 & 0.930 & 1.075 \\
\hline STATE & -0.013 & 0.039 & -0.025 & -0.339 & 0.736 & 0.898 & 1.114 \\
\hline TANG & 0.18 & 0.071 & 0.191 & 2.520 & 0.014 & 0.867 & 1.154 \\
\hline TAX & -0.036 & 0.025 & -0.103 & -1.416 & 0.160 & 0.935 & 1.069 \\
\hline UNI & 0.075 & 0.08 & 0.073 & 0.942 & 0.349 & 0.819 & 1.221 \\
\hline a. Dependent & le: STD & & & & & & \\
\hline
\end{tabular}

(Source: The researchers' collecting data and SPSS 20.0)

Table 2 showed that all nine variables surveyed that is very reliable. Such observations make it eligible for the survey variables after the testing. This factor showed that data was suitable and safe for researching. The STD eliminated: the SIZE, the STATE, marginal tax rate (TAX), and UNI are not significant at 5 percent.

From the model, we can conclude:

The STD influenced by the following factors: FA, GRO, LIQ, ROA, and TANG, with significance at 5 percent. This factor showed that the real estate industry is a relatively particular economic sector with products with distinctive characteristics: products which usually have long-term investment capital, products with long-lasting durability, associated with a specific position, it takes a long time for an investment to be profitable, the ability to convert into money is less flexible. It is these factors that make it difficult for a company to invest in real estate. The inventory of the real estate industry has its attributes, unlike other manufacturing or consumption industries. Lists of real estate companies including real estate goods are finished products such as apartments, houses. And unfinished products are the value of land use rights, capitalized interest expenses, capital costs. Next, the construction costs of the projects are in the implementation phase. 
International Journal of Small Business and Entrepreneurship Research

Vol.8, No.3, pp.31-42, June 2020

Published by ECRTD-UK

Print ISSN: 2053-5821(Print), Online ISSN: 2053-583X (Online)

Table 3: Tested results of model 3 for factors affecting the financial leverage of real estate companies listed on the stock market in Vietnam

\begin{tabular}{|c|c|c|c|c|c|c|c|}
\hline \multirow{2}{*}{ Model } & \multicolumn{2}{|c|}{$\begin{array}{c}\text { Unstandardized } \\
\text { Coefficients }\end{array}$} & \multirow{2}{*}{$\begin{array}{c}\text { Standardized } \\
\text { Coefficients }\end{array}$} & \multirow{2}{*}{$\mathrm{t}$} & \multirow{2}{*}{ Sig. } & \multicolumn{2}{|c|}{$\begin{array}{l}\text { Collinearity } \\
\text { Statistics }\end{array}$} \\
\hline & B & Std. Error & & & & Tolerance & VIF \\
\hline (Constant) & -0.155 & 0.179 & & -0.865 & 0.389 & & \\
\hline FA & 0.408 & 0.074 & 0.479 & 5.500 & 0.000 & 0.797 & 1.254 \\
\hline GRO & 0.104 & 0.044 & 0.073 & 2.364 & 0.002 & 0.900 & 1.111 \\
\hline LIQ & 0.036 & 0.01 & 0.317 & 3.589 & 0.001 & 0.774 & 1.292 \\
\hline ROA & -1.054 & 0.311 & -0.291 & -3.388 & 0.001 & 0.818 & 1.222 \\
\hline $3 \mathrm{SIZE}$ & 0.085 & 0.026 & 0.141 & 3.269 & 0.001 & 0.930 & 1.075 \\
\hline STATE & 0.035 & 0.033 & 0.088 & 1.071 & 0.287 & 0.898 & 1.114 \\
\hline \begin{tabular}{|l} 
TANG \\
\end{tabular} & 0.117 & 0.041 & 0.160 & 2.854 & 0.007 & 0.867 & 1.154 \\
\hline TAX & 0.045 & 0.022 & 0.167 & 2.080 & 0.041 & 0.935 & 1.069 \\
\hline UNI & -0.191 & 0.068 & -0.241 & -2.807 & 0.006 & 0.819 & 1.221 \\
\hline a. Dependent & ole: LTD & & & & & & \\
\hline
\end{tabular}

(Source: The researchers' collecting data and SPSS 20.0)

Table 3 showed that all nine variables surveyed that is very reliable. Such observations make it eligible for the survey variables after the testing. This factor showed that data was suitable and safe for researching. The LTD eliminated: the STATE is not significant at 5 percent.

From the model, we can conclude:

The LTD influenced by the following factors: FA, GRO, LIQ, ROA, SIZE, TANG, TAX, and UNI with significance at 5 percent. This factor showed that the real estate industry has a long business cycle, significant capital demand, companies rely on three primary sources of capital, equity, loans from credit institutions, and customer advances. This characteristic has the most significant impact on the capital structure of real estate companies, because of the advanced capital from customers. This capital is relatively large, but it is recorded in the short-term debt in the balance sheet, making the capital structure of real estate enterprises much researched. Debt in which the short ratio also accounts for more than the long-term debt of the business.

\section{CONCLUSIONS \& MANAGERIAL IMPLICATIONS}

\section{Conclusions}

The empirical research results show that the factors affecting the capital structure decision of real estate enterprises in Vietnam are quite similar to the theory and practice of other countries. These relationships are easily explained by the structural theories, as mentioned. This study has identified the factors affecting the capital structure of enterprises through the regression model. 
International Journal of Small Business and Entrepreneurship Research

Vol.8, No.3, pp.31-42, June 2020

Published by ECRTD-UK

Print ISSN: 2053-5821(Print), Online ISSN: 2053-583X (Online)

The study results showed that the elements: LIQ, the ROA, and UNI have an inverse effect on capital structure, while SIZE, GRO, and TANG have a direct impact on capital structure. Research results showed that The LTD influenced by the following factors: FA, GRO, LIQ, ROA, SIZE, TANG, TAX, and UNI with significance at 5 percent. The researchers had managerial implications policymaker for the financial leverage of real estate companies listed on the stock market in Vietnam following.

\section{Managerial implications}

Based on results as mentioned above and the researchers had managerial implications flowing:

(1) The research results showed that constructing the capital structure, real estate companies need to pay attention to the following factors: the proportion of tangible fixed assets to total assets, growth rate, liquidity, returns, tangible assets, taxes, and product characteristics.

(2) To maintain stable operation, real estate companies must change their capital structure to reduce short-term debt, find medium and long-term funding sources.

(3) Real estate companies including real estate goods and real estate are under construction, given the current real estate market situation, their ability to sell products very difficult, credit capital from banks is shrinking, businesses are in a severe shortage of money, leading to projects in the process of unfinished construction must also be delayed. Therefore, the ability to recover capital to pay short-term debts when they are due complicated.

(4) Companies should adjust their planning, improve the structure of apartments to suit the needs and solvency of the market, usually to reduce the size of flats because the demand for housing for low-income people The current is very high.

(5) State management agencies need accurate forecasts and significant impacts to warm up the real estate market. To improve the real estate market with transparent information on supply and demand in the market, organize a professional real estate trading floor, limit speculation, and price stimulation, develop a complete legal framework.

(6) The Ministry of Finance should also support real estate companies during this challenging period by reducing corporate income tax rates, extending the tax payment schedule.

(7) The Government amended, supplemented, and expanded the conditions for foreigners to own apartments in Vietnam, contributing to stimulating the housing market.

(8) The State Bank of Vietnam focuses on implementing programs to support and solve difficulties for businesses and the real estate market with solutions to deal with bad debts with real estate assets; solutions on currency and banking credit, contributing to solving difficulties, creating favorable conditions for the operation of enterprises and banks to stabilize and develop.

\section{REFERENCES}

Bauer, P. (2014). Determinants of capital structure: empirical evidence from the Czech Republic. Czech Journal of Economics and Finance, 54(1), 2-21.

Bhaduri, Saumitra N. (2015). Determinants of capital structure choice: a study of the Indian corporate sector. Journal of Business Research, 1(2), 13-25.

Chen, J. J. (2017). Determinants of the capital structure of Chinese-listed companies. Journal of Business Research, 4(6), 25-31. 
International Journal of Small Business and Entrepreneurship Research

Vol.8, No.3, pp.31-42, June 2020

Published by ECRTD-UK

Print ISSN: 2053-5821(Print), Online ISSN: 2053-583X (Online)

Gulnur Muradoglu (2018). Determinants of Capital Structure: Empirical Evidence from Turkey. Journal of Management and Sustainability, 8(1), 31-45.

Hair, B. B., \& Anderson (2010). Multivariate Data Analysis (7th ed.). New York: US: Pearson Prentice Hall.

Hair, J., Anderson, R., Tatham, R., \& Black, W. (1998). Multivariate Data Analysis with Readings. US: Prentice-Hall: Upper Saddle River, NJ, USA.

I. M. Pandey (2016). Capital Structure and the Firm Characteristics: Evidence from an Emerging Market. Journal of Financial Economics, 3(4), 34-46.

Joy Pathak (2014). What Determines the Capital Structure of Listed Firms in India? Empirical Evidence from The Indian Capital Market. Journal of Financial Economics, 12(3), 123136.

Lee, C. F. (2018). Determinants of capital structure choice: A structural equation modeling approach - the Quarterly Review of Economics and Finance.

Mackies-Mason J. (2015). Do taxes affect corporate financing decisions? American Economic Review, 12(1), 145-151.

Myers J. K. (2017). Determinants of corporate borrowing. Journal of Financial Economics, $34(5), 12-23$.

Ozkan, A. (2016). Determinants of capital structure and adjustment to long-run target: evidence from UK company panel data. American Economic Review, 15(2), 156-167.

Paudyal, K. (2017). The determinants of capital structure: evidence from the Asia Pacific region. Journal of Multinational Financial Management, 14(4), 387-405.

Raviv, A. (2017). The Theory Of Capital Structure. The Journal Of Finance, 46(1), 297-355.

Vidhan K. Goyal (2016). Capital Structure Decisions: Which Factors Are Reliably Important. American Economic Review, 15(6), 323-335.

Wessels, R. (2017). The determinants of capital structure choice. The Journal of Finance, 43(1), $1-19$.

Wiwattanakantang Y. (2017). An empirical study on the determinants of the capital structure of Thai firms. Pacific-Basin Finance Journal, 17(4), 324-331.

Yermack, D. L. (2016). Managerial entrenchment and capital structure decisions. The Journal of Finance, 52(4), 1411-1438.

Zou, H. (2017). The financing behavior of listed Chinese firms. The British Accounting Review, $38(3), 239-258$. 